\title{
Non-for-Profits and EU Citizens' Cross-Border Social Rights in Different Welfare States
}

\author{
CECILIA BRUZELIUS \\ University of Tübingen, Institute of Political Science, Research Unit Comparative Public \\ Policy, Melanchthon Strasse 36, D-72074 Tübingen, Germany \\ email: Cecilia.Bruzelius@uni-tuebingen.de
}

\begin{abstract}
This paper looks at rights in practice to understand how migrant EU citizens' formal social rights translate into substantive ones. It highlights a factor thus far overlooked in the literature on welfare states and migrants' social rights: namely, the actors involved in welfare delivery. The argument is based, first, on non-profit organisations' (NPOs) function as 'rights intermediaries'; and second, on the distinct make-up of the 'welfare mix' across countries, with which NPO's role in the provision of services, and hence their capacities and autonomy, varies. Focusing on EU citizens' cross-border social rights, and drawing on in-depth research in Germany and Sweden, the paper reveals how NPOs defend and facilitate access to rights in both countries. Yet NPOs' extensive role in the German welfare sector generates greater capacities for NPOs to pursue inclusive objectives than what is available to their Swedish counterparts, which occupy a much more limited position as welfare providers. This, it is argued, can be important for understanding how boundaries of social citizenship are drawn in each country.
\end{abstract}

\section{Introduction}

Research has shown how different welfare states shape migrants' social inclusion (Schmitt and Teney, 2018; Römer, 2017; Ruhs, 2013; Sainsbury, 2012). The predominant focus of this research is formal rights and associated entitlement principles (e.g. residence vs contribution). Yet formal rights do not translate into the same substantive rights for all entitled (Sainsbury, 2012: 4). This paper suggests that one factor behind such discrepancies is tied to the institutional makeup of welfare states.

This argument is predicated, first, on non-profit organisations' (NPOs) function as 'rights intermediaries'; and second, on the distinct make-up of the 'welfare mix' across countries, with which NPO's role in the provision of services, and hence their capacities and autonomy, varies. NPOs can be expected to matter for migrants' ability to exercise rights because of their traditionally important role in defending vulnerable groups' rights and addressing social 
needs of those not entitled to statutory provision. Yet, NPOs ability to perform this function likely depends on their position in the welfare state. In welfare states where NPOs are central to welfare provision, these organisations have more resources and capacities at hand than where they play a marginal role. Equally, where traditions of third sector provision prevail, state-funded NPOs often have comparatively large autonomy even when contracted by the state, possibly leaving them with greater capacity and leeway to address groups lacking, or with unclear, formal entitlements.

One such group is EU citizens. ${ }^{1}$ The social rights that EU citizens enjoy in EU member states other than that of nationality are often vaguely defined and subject to (poor) national implementation, making intermediaries that defend and support rights claims potentially very important. And in contrast to e.g. undocumented migrants, EU citizens do have rights, creating real opportunities for NPOs to support this group of migrants.

Against this background, this paper asks (1) in what ways NPOs shape EU citizens' substantive social rights (2) how their ability to do so is conditioned by their position in the welfare state. Drawing on research conducted in two EU member states where NPOs occupy fundamentally different positions in the respective welfare state - Germany and Sweden - it is argued that, whilst NPOs safeguard and facilitate access to social rights in both countries, their much more prominent role in the German welfare state provides German NPOs with greater capacities to pursue inclusive strategies relative to their Swedish counterparts. This, it is argued, could be important for understanding how boundaries of social citizenship are drawn in each country.

The paper proceeds as follows. The first part situates the paper in relation to existing research on intra-EU migrating EU citizens' social rights and research on NPOs as social rights defenders and welfare providers. Following this, the research design is elaborated, before proceeding to the empirical analysis. The concluding part summarises and discusses the findings.

\section{Determinants of EU citizens' cross-border social rights}

Migrants' social rights ${ }^{2}$ are fundamentally shaped by the legal status they hold and by the welfare system in the country to which they migrate (Shutes, 2016; Sainsbury, 2012; Morris, 2003). ${ }^{3}$ EU citizens constitute a very particular category of migrant in the EU context, as they enjoy the right to freely enter other EU member states. In accordance with EU non-discrimination principles, they also have conditional rights to access social benefits and services in the member state of destination. The right to reside in another member state for more than three months as well as their social rights in that member state are conditioned on worker status and economic resources. ${ }^{4}$ Whereas those who qualify as workers cannot lawfully be treated differently from national workers in the country of 
destination, and hence are entitled to social benefits and services in that member state, economically inactive movers are not entitled to equal treatment and are largely dependent on exportable benefits from the country of origin (Bruzelius et al., 2017). After five years of continuous and legal residence, EU migrant citizens can obtain permanent residence and can no longer be lawfully discriminated against. This makes the five first years in another member state a period in which EU migrant citizens' legal status is subject to significant change depending on socio-economic circumstances.

These formal rights are defined at EU level, yet the substantive rights they translate into are largely defined by member states. First, member states' different social systems determine the availability and generosity of benefits and services. Second, member state implementation of EU law is crucial for de facto access to available social benefits. EU citizens' formal rights to reside and to social benefits in the country of destination are often legally complicated, politically contested and subject to national political interpretation and implementation (Martinsen and Werner, 2018, Kramer et al., 2018). For example, research on street-level bureaucracy shows that discrimination in social administrations hamper immigrants', and EU citizens' specifically (Lafleur and Mescoli, 2018), ability to successfully claim rights (Henker and Rink, 2017).

The latter highlights that social rights and boundaries of social citizenship cannot be comprehended without studying social rights in practice. Formal rights are conditioned and distorted as policy is put into practice, meaning that substantive rights are the outcome of numerous different, overlapping and at times contradictory regulations, and are shaped by different actors and practices (Carmel, 2013; Morris, 2003). Accordingly, we ought to investigate the process whereby formal rights translate into substantive rights, and the factors that condition access.

It is in this connection that this paper proposes an additional perspective for understanding EU citizens' cross-border social rights. Specifically, it argues that we should move beyond a comparison of formal entitlement principles to include also other dimensions of what we refer to as the welfare state (Kaufmann, 2014:12). One such dimension is the delivery, or production, of welfare, i.e. the ways in which social rights are substantiated. As will be clarified in the following, there are strong reasons to expect that NPOs and their role in the production of welfare could have implications for EU citizens' substantive rights.

\section{Non-profit organisations as social rights intermediaries and providers}

NPOs are significant for social rights and migrants' social protection in several ways. To begin with, NPOs have been and continue to be important sources of 
social support for those who fall through the gaps of standard social safety nets, a category to which certain migrants belong (Leerkes, 2016; Randall, 2015). As examples can be mentioned, first, how many NPOs and other non-governmental organisations stepped in to provide social protection to migrants where governments have not in the context of the 2015 European 'migration crisis' (EESC, 2017; Garkisch et al., 2017). Or how, at times, NPOs collaborate with local governments to jointly provide health care to those lacking formal entitlement (PICUM, 2017).

Beyond providing discretionary social support to migrants' lacking entitlement, NPOs have been central actors in furthering formal social rights by promoting human rights more generally and advocating for economic and social rights specifically (Chong, 2008). Human rights-oriented non-governmental organisations have lobbied for international treaties and national legislations to include individual economic and social rights, pushing for them to be made legally enforceable (ibid.). Likewise, NPOs have often been pivotal to the realisation of formal social rights as defined by states, taking a crucial role in 'mobilising' laws that have direct or indirect bearing on rights - which is to say that they routinely act as intermediaries between individuals and the state, thereby 'giving force' to legal social rights (O’Brien, 2012). In so doing, NPOs typically represent the interests of those who lack political representation or the resources to challenge the status quo themselves (Dahme and Wohlfahrt, 2013: 130).

NPOs can be expected to play a role in supporting EU citizens' social rights in member states for two key reasons. First, because EU citizens, in contrast to other categories of migrants (e.g. undocumented) that NPOs may target in their efforts, enjoy a legal status that comes with certain fundamental rights (in particular time-limited freedom of movement) and the possibility to enjoy additional rights when certain conditions are fulfilled. This creates real opportunities for NPOs to support EU citizens' exercise of rights. The argument here is not that NPOs extend (statutory) formal rights or change their substance, ${ }^{5}$ but that they can be imperative to whether and how formal rights translate into substantive ones.

Second, demand for such support is likely to exist. As described above, EU citizens' rights are conditional, changeable and sometimes legally unclear, resulting in a number of barriers for EU citizens to benefit from these rights. Research has also shown that EU citizens often do not know their rights (Ehata and Seeleib-Kaiser, 2017). Analytically, we can distinguish two types of barriers: (1) barriers to entitlement and (2) barriers to accessing rights one is formally entitled to. For example, worker status implies a right to access social benefits on the same grounds as nationals. Not being a worker is thus a barrier to entitlement. However, also for those who are workers, barriers to exercising the rights that one is formally granted may be in place, e.g. administrative barriers. 


\section{Institutional context: autonomy and resources}

However, NPOs' ability to support EU citizens may be conditioned on their role in, and relationship to, the welfare state. The nature of the voluntary sector state relationship (in terms of funding, conditions and expectations) in regards to social provision varies over time and place (Lewis, 1999). This relationship is constituted both in terms of how it is politically conceptualised - e.g. whether civil action is seen as part of the fabric of the state or rather as an independent counterweight to a bureaucratic state - but also, and more concretely, in the degree of independence that civil society is left when receiving public funding (ibid.). These tensions are very much evident in the area of welfare service delivery and vary with type of welfare state. In some countries, NPOs are central to the delivery of social services, while they play only very marginal and complementary roles in others (Evers and Laville, 2004). With this comes distinct relationships between NPOs and the state.

In many continental, conservative welfares, the voluntary sector is the dominant service provider as a result of corporatist structures and the principle of subsidiarity (Arts and Gelissen, 2002: 142), i.e. that public bodies must refrain from providing services if there is an NPO performing the same function. In such countries, voluntary organisations - often religious - receive state funds to engage in diverse provision (Lewis, 1999: 260).

Across social democratic and in some liberal (the UK) welfare states, the state has in contrast dominated welfare service provision and NPOs have primarily fulfilled expressive functions, giving voice to unmet needs of citizens (Johansson et al., 2015; Henriksen et al., 2012: 468). As part of new public management and choice reforms, NPOs in such welfare states have been encouraged to provide statutory welfare services. However, the contractual relationship implicated in this shift appears to have come at the expense of loss of NPO independence and standardisation of services (Henriksen et al., 2012: 468, 471; Macmillan, 2010).

Voluntary social service providers in conservative welfare states have also been subject to new public management reforms. In countries like Germany, such reforms appear to have resulted in cost-cutting pressures and challenges to the privileged position of voluntary welfare organisations as welfare providers as NPOs and private providers have been given greater possibilities to engage in public provision (Henriksen et al., 2012: 475-482). Nevertheless, the German 'voluntary welfare organisations' (more on these below) have retained their dominant standing as welfare providers and retained much autonomy - they do for example enjoy significant leeway in charging fees (ibid., 479). Although autonomy is hard to measure and pin-down, not the least because of the often hybrid and complex relationship between different actors (Goul Andersen, 2012; Evers, 2005), it would thus appear that in welfare states where 
NPOs have long been key service providers they continue to enjoy greater autonomy to define their practices and resources to act beyond state mandates.

Such differences in welfare production may have implications for substantive social rights. Service delivery characterised by more plurality comes with greater diversity of objectives, leading to practices more variable than were it predominantly the state that defines target groups - with its consideration for constituencies, social budgets, border control and regulation of national membership. Following from the related resources and degrees of autonomy, NPOs in states with more diverse welfare sectors may also have greater abilities to pursue their own objectives. The broader question addressed in this paper is thus what impact a more diverse, and comparatively autonomous, set of welfare providers has on the substantive demarcations of social citizenship. More specifically, the paper addresses two key research questions. First, in what ways do NPOs shape EU citizens' substantive cross-border rights? And, second, how is their ability to do so conditioned by their position in the welfare state?

\section{Research design}

To answer the two questions, the paper draws on research from an in-depth qualitative study of barriers to EU citizens' rights conducted in 2015-2016. The research was carried out in Germany and Sweden, predominantly at the local/municipal level where many social rights are exercised and accessed. The two countries are comparable in so far as they are both net-destination EU member states, but differ with respect to the variable of interest - i.e. NPOs role in the respective welfare state.

German 'voluntary welfare associations' are central to the delivery of welfare services, in line with the subsidiarity principle (Evers and Olk, 1996), with a market share of just under 50 per cent (Merchel, 2010: 245). These associations act under public law defined at federal and state level with the support of public funding. The welfare associations are guided by different normative understandings and traditions and have also been referred to as 'world-view associations' (Weltanschauungsverbände) (Dahme and Wohlfahrt, 2013: 131).

NPOs in Sweden have in contrast played a very marginal role in delivering welfare services and their main role has been to act as independent counterweights, giving voice to weak groups (Johansson et al., 2015: 1603; Lundström and Svedberg, 2003). If anything, non-profit actors have been judged to have a complementary role in the Swedish welfare system (Johansson et al., 2015: 1611). Whilst a shift has occurred in the past two decades from public towards many more non-state actors as welfare providers, these tend to be for-profit organisations (Blomqvist and Winblad, 2017).

In terms of internal EU migration, Germany and Sweden belong to the old member states, within or to which EU citizens primarily move (Recchi, 2015). 
TABLE 1. EU citizens (excluding reporting country) in Germany in Sweden in 2015

\begin{tabular}{llll}
\hline & $\begin{array}{l}\text { EU citizens from } \\
\text { percentage of total } \\
\text { population* }\end{array}$ & $\begin{array}{l}\text { post-2004 member } \\
\text { states as a percentage } \\
\text { of all EU citizens* }\end{array}$ & $\begin{array}{l}\text { EU citizens as a } \\
\text { percentage of all } \\
\text { immigrants** }\end{array}$ \\
\hline $\begin{array}{l}\text { Germany } \\
\text { Sweden }\end{array}$ & 4,3 & 44 & 30 \\
\hline
\end{tabular}

Source: *Eurostat, 2018a; ${ }^{* *}$ Eurostat, $2018 \mathrm{~b}$

As of 2015 (when the study was carried out), the stocks of EU citizens in Sweden were at an EU average of 3 percent of total population; whilst, in Germany, EU citizens made up about 4.3 percent of the population (Table 1). Germany also had a slightly higher share of EU citizens from new member states.

Data were collected chiefly through semi-structured interviews in two major cities in each country (Gothenburg, Stockholm, Berlin and Hamburg), with public administrations, migrant support groups and other stakeholders (such as municipal associations). Interviews with national stakeholders were also included. Further data were obtained from organisational, local and national policy documents. A total of 45 interviews (22 in Sweden and 23 in Germany) were conducted, 18 of these were with NPOs. Permissions to use the interviews have been obtained.

Organisations that address EU citizens' social needs were identified through positional criteria (Tansey, 2007: 19-20). In the Swedish cities, what appears to be the entire population of relevant organisations could be identified and most interviewed. ${ }^{6}$ In the German cities, the number of organisations is much larger, therefore only a selection was interviewed. These were selected according to the type of service they provide: 1) general (not targeting EU citizens) migrant counselling services (to which EU citizens can under certain circumstances have access), and 2) services targeting EU citizens specifically. Interviewed organisations are listed in table 2.

The ways NPOs address barriers that EU citizens face in exercising social rights is taken to represent how NPOs shape EU citizens' substantive social rights. Such barriers were identified through interviews with a variety of stakeholders, including the NPOs. Interviews were analysed with qualitative thematic analysis, using a chiefly inductive process. The analysis pointed to the significance of distinct governance structures for type of support provided. This was probed further by means of document research, follow-up and additional interviews. Two things were examined at this stage: sources of funding and any specific mandates/ contracts under which interviewed NPOs operated. Based on this, their relationship to the state and autonomy to support EU citizens could be inferred. 
TABLE 2. Interviewed NPOs

\begin{tabular}{|c|c|c|c|}
\hline & & Name of Organisation & Brief description \\
\hline \multirow[t]{12}{*}{ GERMANY } & \multirow[t]{6}{*}{ BERLIN } & Amaro Foro & $\begin{array}{l}\text { Counselling in Bulgarian, } \\
\text { Romanian and Romanes. }\end{array}$ \\
\hline & & $\begin{array}{l}\text { Caritas Mobile Contact } \\
\text { Point for European } \\
\text { migrant workers and } \\
\text { Roma. }\end{array}$ & $\begin{array}{l}\text { Counselling. Focus on Southern } \\
\text { and Central Eastern European } \\
\text { (CEE) citizens. }\end{array}$ \\
\hline & & $\begin{array}{c}\text { Diakonie Simeon, Migrant } \\
\text { Counselling for Adults }\end{array}$ & $\begin{array}{l}\text { Counselling. Focus on Bulgarian } \\
\text { and Romanian citizens. }\end{array}$ \\
\hline & & Fair Mobility & $\begin{array}{l}\text { Counselling for migrant EU } \\
\text { workers. Focus on CEE } \\
\text { citizens. }\end{array}$ \\
\hline & & Frostschutzengel & $\begin{array}{l}\text { Mobile social counselling. } \\
\text { Provision of basic needs for } \\
\text { homeless. Focus on CEE } \\
\text { citizens. }\end{array}$ \\
\hline & & Polish Social Council & Counselling in Polish \\
\hline & \multirow[t]{6}{*}{ HAMBURG } & $\begin{array}{l}\text { Work and Life. } \\
\text { Information Centre } \\
\text { Labour Mobility }\end{array}$ & $\begin{array}{l}\text { Counselling for migrant EU } \\
\text { workers. Focus on CEE } \\
\text { citizens. }\end{array}$ \\
\hline & & $\begin{array}{l}\text { Diakonie, Migrant } \\
\text { Counselling for Adults }\end{array}$ & $\begin{array}{l}\text { Counselling in different } \\
\text { European languages. }\end{array}$ \\
\hline & & $\begin{array}{l}\text { Diakonie Housing } \\
\text { Support }\end{array}$ & $\begin{array}{l}\text { Support for homeless. Provision } \\
\text { of basic needs, shelter, social } \\
\text { counselling. Focus on CEE } \\
\text { citizens. }\end{array}$ \\
\hline & & $\begin{array}{l}\text { Office for Immigration } \\
\text { from South-eastern } \\
\text { Europe, Diakonie } \\
\text { Hamburg }\end{array}$ & $\begin{array}{l}\text { Counselling. Focus on CEE } \\
\text { citizens. }\end{array}$ \\
\hline & & $\begin{array}{l}\text { SOS - South-eastern } \\
\text { Europe Service Centre, } \\
\text { City Mission }\end{array}$ & $\begin{array}{l}\text { Counselling in Romanian, } \\
\text { Bulgarian and Romanes. }\end{array}$ \\
\hline & & $\begin{array}{l}\text { Verikom, Migrant } \\
\text { Counselling }\end{array}$ & Counselling for migrants. \\
\hline \multirow[t]{5}{*}{ SWEDEN } & \multirow[t]{3}{*}{ GOTHENBURG } & Bräcke Diakoni & Shelter for EU citizens. \\
\hline & & Crossroads, City Mission & $\begin{array}{l}\text { Basic needs, counselling in } \\
\text { various European languages. }\end{array}$ \\
\hline & & $\begin{array}{l}\text { Gothenburg Rescue } \\
\text { Mission }\end{array}$ & Basic needs, shelter. \\
\hline & \multirow[t]{2}{*}{ STOCKHOLM } & Crossroads, City Mission & $\begin{array}{l}\text { Basic needs, counselling in } \\
\text { various European languages. }\end{array}$ \\
\hline & & $\begin{array}{l}\text { Social Centre, Salvation } \\
\text { Army }\end{array}$ & $\begin{array}{l}\text { Basic needs, shelter for EU } \\
\text { citizens. }\end{array}$ \\
\hline
\end{tabular}

Though interviews with migrants would be necessary to confirm what barriers individual migrants face, the assumption is that NPOs that support migrants possess knowledge of common problems and how they apply to various groups of migrants, as well as institutional frameworks, regulations, 
etc. with bearings on rights, and hence can provide a broader perspective of barriers. As a result of this, the research presented here cannot confirm the significance of NPOs support for migrants' substantive rights, but point to its probable significance.

\section{How NPOs shape substantive social citizenship}

To begin with, what barriers do NPOs address and how? One critical category of barriers that EU citizens face in exercising rights pertains to basic needs. The common assertion that a modicum of social rights is required to enjoy other rights (Marshall, 1950) is paradoxically reversed for EU citizens, as exclusion from social entitlements itself becomes a barrier for eligibility. Due to the limited conditions under which EU citizens are entitled to access social support in the destination country, EU citizens - especially those from Central Eastern member states - who arrive as jobseekers regularly end up in destitution (Ger4; Ger9; Swe2). Unmet basic needs in turn heavily influences one's ability to find work and gain worker status.

To address insufficiently met basic needs, several NPOs provide material assistance for those not entitled to other public provisions. This consists primarily of outreach work and the provision of shelter and food, but at times support beyond traditional homeless care work is also offered. In Berlin, one NPO has bought two apartment buildings to provide some EU citizens access to better housing (Ger1). And, occasionally, some German organisations offer economic support. One Diakonie migration counselling office reported using organisational funds to support individuals without access to regular social minimum benefits: for example, by paying parts of their rent (Ger6). In Germany, NPOs occasionally also address basic needs by appealing in local social courts to the human dignity clause in the German constitution, through which they may succeed in securing some time-limited cash-support (Ger2; Ger9; Ger6). This prolongs the time the migrant has to look for work and transition to worker status.

Beyond basic needs, we find numerous barriers tied to implementation and bureaucracy. Language barriers are very common. Although service providers are often legally obliged to ensure that the individual understands, and thus to provide adequate translation service, authorities often fail to deliver on this obligation (Ger1; Ger2; Ger4; Ger11). However, several interviewees suggested that discrimination of certain nationalities, rather than limited language competences, is the core issue (Ger5). Certain nationalities are regularly turned away from welfare authorities before an assessment of their claim has been made (Ger4; Ger10; Ger 12; Swe3) and are often treated in a blanket, collective, way, rather than given individual assessments (Ger2; Ger 10; Swe3; Swe7). Moreover, EU citizens often received oral rather than written responses to rights claims (Ger7; Ger4; Swe3, Swe4), making it difficult to dispute decisions. 
Incorrect processing of rights claims was also attributed to insufficient knowledge of EU rules in social administrations (Ger10, Swe2). As one of many examples, one interviewee spoke of 'ignorance in the institutions, sometimes they even ask for a visa' (Ger3). This points to poor implementation, which the interviews generated ample examples of, and which has been emphasised also in other research (Ehata and Seeleib-Kaiser, 2017). Moreover, individuals tend to lack knowledge of their rights as EU citizens, and of how to benefit from these. In the words of a social worker in Berlin:

They [EU citizens] are not really aware of their rights ... they go somewhere [to a public agency] and ask for help... [they are told] yes or no ... and then if it is no: 'ok then it must be no'. They think they ask for help, but they don't think 'I go there to claim my rights'. (Ger5)

Even for those aware of their (possible) entitlements, understanding the exact formal requirements and how to satisfy these can be very difficult. In both countries, there are significant challenges to obtaining various documents that effectively function as preconditions for claiming rights (Nicolaou, 2018).

NPOs have responded to such issues in various ways. First, most organisations support right claims by providing individuals with relevant information about the destination member state and its public institutions and social system. An illustrative example is how some German organisations help clients gather all necessary documents before making a benefit claim for social assistance. This is crucial, as the deadline to complete certain applications is less than two weeks, but the many documents required may take months to gather (Ger9). Social workers know when and to what someone may be entitled, in a way individuals often do not. A social worker providing counselling for homeless EU citizens in Berlin describes:

Some of our clients have already worked. Some have even been here for five years, and thus can have [a] permanent right to reside [which can be a basis for social benefits]. So, ... we always try to ask: 'Have you worked - even for one day? Do you have a statement showing your salary? Etc.' ... To try to prove that they have not been just jobseekers [during the five years] and therefore be able to make some claims as EU citizens. Or do you maybe have a child here that goes to school? That gives you another reason [eligibility for social support]. (Ger4)

To address deficient knowledge and translation services, and discrimination in public authorities, several organisations accompany individuals personally to their appointments with different authorities. This way, they seek to guard against discriminatory treatment and inform case workers of the legally correct procedures (Ger3; Ger4; Ger8; Ger9; Ger10; Swe2), thus pushing for better implementation of EU law. In the words of one interviewee in Germany:

Sometimes when they [the EU citizens] go alone they get told: 'No, you do not have any rights' ... although they actually do! It is not just about language, the importance of the person who accompanies is that we really know their rights and can be stubborn about them. (Ger3) 
Similar things were reported in Sweden:

We have unfortunately experienced quite a few cases of discrimination. That is of course disappointing, but at the same time it is good, because those times we have demanded to speak to the boss and after that the whole office has started behaving properly, since everyone has been informed. (Swe2)

Some organisations provide language courses to help migrants who cannot access publicly provided language courses (e.g. Crossroads and Phinove). This amounts to a form of 'indirect enabling', as local language competency improves chances of finding work.

NPOs have sought to improve the implementation of EU law also through other means. Some offered more formalised education of relevant EU law for employees and administrations in public authorities (Ger2; Ger5; Swe2). NPOs have also used indirect means and third-party channels to try to enforce EU law. Crossroads Gothenburg has, for example, reported Sweden to the EU Commission for incorrect application of the free movement directive, because of the Swedish residence registration system which raises severe challenges for EU citizens (Bruzelius, 2018). Finally, some organisations also support social rights access through legal appeal. This is much more common in the German organisations than the Swedish, which is connected with differences in the legal character of social rights in each country (Stendahl and Swedrup, 2016).

In sum, NPOs seem to provide important support for EU citizens, enabling access to social rights to which they are entitled, as well as assisting them in becoming eligible. It is important to note that, while we would have expected functionally equivalent forms of support available in Sweden from other, especially public, providers, this does not seem to be the case. Rather, several Swedish public administration employees highlighted how important the work of Crossroads is, as no equivalent services exist (Swe6; Swe2; Swe7). One interviewee from the employment services said:

It has been so good to work with Crossroads - because very much it's after all about information about society. That is what is missing [in Sweden] somehow. (Swe8)

\section{Autonomy and support}

The above section demonstrated many parallels between the two countries. However, clear differences emerge when we look closer at i) who does what, and the ii) the governance structures under which NPOs operate.

\section{Germany}

Most of the organisations interviewed in Germany are tied to one of the voluntary welfare association (Diakonie and Caritas; table 2), which provide many publicly funded services, one of which is migrant counselling. The biggest 
part of their revenue consists of public funding received to deliver certain social services. In addition, they raise their own funds through fees and charitable giving (Anheier and Seibel, 2001: 99-101). This allows them quite some scope to act independently of public funds, as reflected in that certain interviewed German NPOs were financed exclusively by a voluntary welfare association.

Diakonie in Hamburg is an illustrative example. One of their undertakings, 'Diakonie Housing Support', experienced growing numbers of clients from Central Eastern Europe. They recognised a need for counselling concentrating specifically on these EU citizens, as many new clients needed support other than what the Housing unit (with its focus on homelessness) could offer (Gerg; Ger10). Consequently, Diakonie established the 'Office for Eastern European Immigration', where health insurance and social benefit issues are the foci. This was financed exclusively via Diakonie's own resources - with 'church money' as an interviewee from the organisation put it (Ger10). Similarly, in Berlin we similarly find Frostschutzengel, which is an organisation initiated by independent social workers and financed jointly by Caritas and GEBEWO Berlin (part of Diakonie) independent of state funding (Frostschutzengel, 2016).

It also follows that the project-specific branches of larger NPOs that operate partly with state funds (for example, the Diakonie Housing Support) can draw on the voluntary welfare associations' internal resources. As such, these organisations, and organisation-related projects, have room to manoeuvre and to more freely choose their ends without constraints imposed by various regulative frameworks of the local or federal state. Recall also the above example where a Diakonie counselling office offered financial support (Ger6); no similar example was given in Sweden.

The entrenchment and multitude of voluntary welfare associations and their ability to establish smaller projects create scope for sizable networks of support and divisions of labour to develop, generating genuine opportunities to support EU citizens. We saw the example of Diakonie in Hamburg, where separate services were set up within a single organisation. An additional example of multiple organisations cooperating to support EU citizens is another Diakonie migrant counselling office in Berlin. They cooperate closely with Amaro Foro - a recently founded NPO financed partly by the Berlin State that provides counselling in Romanian, Bulgarian and Romani - drawing on their distinctive competencies, capacities and networks. In the words of a social worker from the Berlin Diakonie counselling office:

... we sometimes have the possibility to ... for example, if someone cannot pay their rent, ... get a donation, from some charity or from church collects, so that the rent can be paid for a month. In this respect, we have different possibilities, than for example Amaro Foro. Our counselling exists since many years, so we of course have a very different network that we can draw on. But what Amaro Foro does is totally important. If it is about sickness insurance 
for example, then you sometimes have to speak to insurance companies in Rumania or Bulgaria. In this respect, they have much more competence and experience. (Ger6)

Frostschutzengel, mentioned earlier, also collaborates with Diakonie and Amaro Foro, providing counselling for homeless persons in Bulgarian and other languages.

The size and resources available to well-established German NPOs enables them to act as co-financiers when their subsidiary projects, or independent NPOs that they fund, seek EU funding (e.g. the ESF or FEAD). The latter requires co-funding from national partners, which will typically be local or national governments. It is not required that co-financiers are state agencies, yet only organisations of the magnitude and position of the German welfare associations have the financial capacity to make such investments. The aforementioned Frostschutzengel-project in Berlin is a case in point. This organisation has repeatedly failed to obtain other forms of state or federal state funds and has operated exclusively on (non-public) funds from Caritas and Diakonie on a year-by-year basis. In 2016, it secured three years of EU funding with the support from the two welfare associations, enabling the organisation to expand activates beyond homeless counselling and engage in more long-term projects (Ger4).

In sum, considering how NPOs in Germany support EU citizens suggests that the subsidiarity principle of the German welfare state provides leverage to certain NPOs' inclusive ambitions and thus sources of support for EU citizens.

\section{Sweden}

NPOs' scope for action in Sweden is likewise shaped by their position in the welfare state. Some Swedish NPOs receive local government funding in the form of 'operational grants'. To obtain these, the organisation must provide a service to municipal residents that fit within the municipal social services' scope (Stockholm, 2013). A typical NPO service funded accordingly is homeless care. Once obtained, organisations should be able to employ the grants without detailed steering by municipalities. However, the promised autonomy appears negotiable. When homeless EU citizens became a salient issue around 2010, Stockholm municipality required that organisations receiving operational grants to provide shelter restrict their services to Swedish ID holders (anonymised). But several organisations ignored the instruction to restrict access, as operational grants account only for part of these organisations' budgets. In the words of one interviewee:

... no one did that of course ... we have our own values... [And] we could help anyways, because we have money from other sources. (anonymised)

Contrasted with the German NPOs, the scope for independent action is nonetheless limited. All interviewed organisations catering to EU citizens 
TABLE 3. Number of employees in selected NPOs in Germany and Sweden (2015-18)

\begin{tabular}{llc}
\hline & NPO & Number of Employees \\
\hline \multirow{2}{*}{ Germany } & Diakonie Berlin-Brandenburg-schlesische & $52000^{1}$ \\
& $\quad$ Oberlausitz & \\
& Diakonie: Germany & $465.000^{2}$ \\
& Caritas Hamburg & $1850^{3}$ \\
& Caritas: Germany & $617.193^{4}$ \\
Sweden & City Mission Stockholm & $278^{5}$ \\
& City Mission Gothenburg & $211^{6}$ \\
& Salvation Army: Sweden & $1135^{7}$ \\
\hline
\end{tabular}

Sources: 1. Diakonie, 2017; 2. Diakonie, 2016; 3. Caritas, 2017; 4. Caritas, 2018; 5. Stockholm City Mission, 2016; 6. Gothenburg City Misson, 2016; 7. Salvation Army, 2016.

in Stockholm and Gothenburg work predominantly in the homeless care sector and consequently do not readily possess the competence, experience or resources to provide more sophisticated forms of support. Nor can they independently apply for EU funds. This is evident in the difference in size between the two largest and most active (in providing support for EU citizens) Swedish NPOs and two of the German voluntary welfare associations (table 3).

With increasing numbers of newly arrived EU citizens ending up in destitution in Gothenburg and Stockholm and growing political salience around these issues, some Swedish organisations have received additional public funding for their work targeting EU citizens. Under a recently developed form of cooperation - an 'Idea Supported Public Partnership' (IOP) - local governments provide partial but targeted funding to NPOs to address societal challenges defined jointly by both parties (Forum, 2017). This form of cooperation is supposed to leave involved NPOs autonomous to decide how to carry out the agreed task.

In Gothenburg, the IOP 'Efforts for migrating EU citizens in Gothenburg' was started in 2014, consisting of four organisations (Gothenburg, 2013). The IOP focused almost exclusively on addressing acute basic needs. One of the included organisations in addition provided more advanced (legal) counselling. Though it is unclear to what extent the latter was in line with the objectives of public funding. Interviewees from said organisation described how the municipality's preferences were not always in line with those of the NPO. The organisation wanted to give more attention to groups other than begging EU citizens - the politically most salient political topic at the time - but expressed frustration with the fact that the municipality: is visible! You do not see these Spaniards looking for work. (Swe2) 
A municipal representative in turn explained that because the municipality has the financial resources, they have the final say in what the IOP partners should do (Swe1).

The scope of action granted to NPOs under the IOP was evidently unclear and power was clearly weighted towards the financier - the state. Increased public funding thus came at the price of closer intertwinement with the state and its limitations on who can benefit from public resources. That is to say, that according to the Swedish municipal law (chapter 1, para. 1), a municipality should deal with matters of common interest that are connected to the municipality's geographical area or its residents. Swedish municipalities can thus lawfully spend municipal money only if it benefits their own residents (SKL, 2014), and most of the EU citizens who need support are not yet officially residents in the municipality (Bruzelius 2018). Finally, the limited financial capacities of the Swedish NPOs is clearly demonstrated in how the City Mission in Gothenburg could not continue their Crossroads project after the organisation experienced significant cuts in funding from the Swedish church (Sjödén, 2019).

In summary, NPOs' position in the Swedish welfare state leaves them with comparatively less capacity to provide support. And where they receive funding to target migrant citizens it is primarily in order to cater to the most basic of needs.

\section{Concluding discussion}

The findings reveal how NPOs can influence EU citizens' ability to become eligible for and to claim social rights. The studied NPOs do not only provide direct support for individuals, but also push for better implementation of law and thus contribute to the implementation and further, contextual, specification of supra-national law. As such, they would seem to play an important intermediary role, negotiating boundaries of European social citizenship at the national and local level.

The findings also strongly indicate that the institutional structures in which NPOs operate condition their ability to respond to EU citizens' needs. When compared, it appears that the tradition of subsidiarity generates greater possibilities for German NPOs to provide additional support for EU citizens, than what is available to Swedish NPOs. As key service providers, German NPOs draw on well-established and sophisticated organisational structures when deciding to offer support beyond their public obligations, which generates layers of sources and means of support. NPOs' very limited role in the Swedish welfare state meanwhile inhibits their capacities to expand support for EU citizens. Though Swedish organisations provide similar services for EU citizens, their abilities to do so are more constrained as a result of limited competences and financial resources. Notably, this is the case despite an absence of statutory 
functional equivalents. Moreover, recent increases in public funding to NPOs to cater to EU citizens has come at the cost of circumscribed autonomy and closer intertwinement with the Swedish state and associated demarcations of social citizenship.

Granted that the demonstrated intermediary function of NPOs is indeed important for some individuals' ability to enjoy social rights tied to their EU citizenship, German NPOs' greater scope for discretion and independent action suggest that, in this particular respect, welfare states characterised by more plurality in service delivery entail additional 'venues' for inclusion of certain migrants. This is not to suggest that macro-oriented research on migrants' social rights is wrong in arguing that social democratic welfare states are the most inclusive: substantive rights ultimately dependent on formal rights, and here universal and generous welfare states are more inclusive than contributionbased and less generous ones (Römer, 2017; Sainsbury, 2012). One way to read the findings is rather that, though the Swedish welfare state is comparatively more inclusive once one has gained footing in it, there exist fewer intermediary actors supporting access for EU citizens to reach that stage. Consequently - and despite universalism often being framed as the normatively superior form of social provision because it is associated with less discretionary provision (Titmuss, 2010) - the less clear demarcation of social citizenship in non-universal welfare states that has been described here could in certain respects be advantageous for specific groups of migrants.

Caveats to these inferences should be mentioned, as observed differences in provision of support could be related also to factors not explored here. First, states (local and national) have their own agendas. It has been shown that Swedish local governments' approach to the third sector and its consequent involvement in local public provision varies significantly (Arvidsson et al., 2018). Similarly, Swedish municipalities have responded differently to destitute EU citizens, e.g. with respect to social assistance payments (SOU, 2016). In Germany, the Berlin city government has, in contrast to many other German municipalities, adopted an inclusive approach towards socioeconomically weak EU citizens (Bruzelius, 2017). This could impact on organisations' capacity to provide the type of support described here - e.g. in terms of public funding received or the absence of hindrances (regulative or political) to provide certain services. However, also in Hamburg - which does not have a similarly inclusive agenda - NPOs offered services targeting EU citizens' inclusion. This was possible thanks to Diakonie's internal resources, not grants from Hamburg city. We can also note that the German federal government has sought to limit EU citizens' access to specific benefits (BMAS, 2016) parallel to voluntary welfare associations' facilitation of access to social rights (which is effectively based partly on public funds). Finally, this research coincided with the arrival of unprecedent numbers of asylum-seekers in both countries, which possibly influenced local governments' 
willingness in support the integration of EU-citizens. The latter is a group that municipalities can chose to ignore, which may seem appealing given strains on local budgets and housing shortages resulting from obligations towards asylumseekers, as well as challenges to integrate previous waves of immigrants.

In terms of agendas, NPOs' motivations to deliver these sorts of services should also be scrutinised. Where public funding (including EU funding) is available to address certain groups and needs, NPOs may be driven as much by financial interests as any humanist values. Likewise, the value orientations of NPOs can lead to discretionary practices (Hien, 2017).

Another caveat relates to possible underlying differences in demand for services related to migration levels and other welfare characteristics. Germany is experiencing higher levels of immigration from other EU member states than Sweden. Equally, past experiences of migration could contribute to NPOs capacities and networks, as these develop over time. Berlin, for example, has a long history of addressing immigration-related social issues. Moreover, universal welfare states like Sweden are associated with lower levels of welfare chauvinism and strong equality norms (van der Waal et al., 2013), all of which may make implementation comparatively more effective in Sweden than in Germany and reduce overall demand for the type of NPO services described here.

To summarise. This paper has demonstrated that looking at rights in practice can help us understand how institutional features of the welfare state other than entitlement principles influence substantive social rights. In particular, the findings suggest that welfare states where social inclusion is less strictly defined by the state those characterised by a greater diversity of welfare providers with comparatively more scope for discretion - can generate additional venues for inclusion.

\section{Acknowledgments}

I am grateful for instructive comments on earlier versions of this article by the two anonymous referees and Martin Seeleib-Kaiser. I also wish to thank my interviewees for their participation and patience.

\section{Notes}

1 'EU citizen' refers throughout the text to EU citizen who have moved between member states and that do not hold the national citizenship of their destination state.

2 Here understood as formalised entitlements to benefits and services, rather than human rights.

3 And the country from which they migrate, but the focus here are rights in the destination country.

4 Directive 2004/38/EC

5 Though they could influence change through giving voice to certain groups and issues.

6 The few organisations not interviewed were very similar in kind (mostly church-based organisations providing shelter) to those already included. 


\section{References}

Anheier, H.K. and Seibel, W. (2001), The Nonprofit Sector in Germany: Between State, Economy, and Society, Manchester/New York: Manchester University Press.

Arts, W. and Gelissen, J. (2002), 'Three Worlds of Welfare Capitalism or More? A State-of-theArt Report', Journal of European Social Policy, 12, 2, 137-58. https://doi.org/10.1177/ 0952872002012002114.

Arvidson, M., Johansson, H., Johansson, S. and Nordfeldt, M. (2018), 'Local civil society regimes: liberal, corporatist and social democratic civil society regimes in Swedishmetropolitan cities', Voluntary Sector Review, 9, 1, 3-20.

Blomqvist, P. and Winblad, U. (2019), 'Why No Nonprofits? State, Market, and the Strive for Universalism in Swedish Elder Care', Non-profit and Voluntary Sector Quarterly, 48, 3, 513-531.

BMAS (2016), 'Clarification of access to social benefits for non-German EU citizens', Federal Ministry of Labour and Social Affairs, October 14, Berlin.

Bruzelius, C. (2017), The local governance of European social citizenship. DPhil thesis, University of Oxford.

Bruzelius, C. (2018), Freedom of movement, social rights and residence-based conditionality in the EU, Journal of European Social Policy, 29, 1, 70-83.

Bruzelius, C., Reinprecht, C. and Seeleib-Kaiser, M. (2017), 'Stratified social rights limiting EU citizenship', Journal of Common Market Studies, 55, 1239-1253.

Caritas (2017), Einrichtungsstatistik, Gesamtübersicht. Zentralstatistic des Deutschen Caritasverband e.V., 31.12.2016.

Caritas (2018), Caritas im Norden. Available at [accessed 14.09.2019]: https://www.caritas-imnorden.de/dicv/caritas-im-erzbistum-hamburg

Carmel, E. (2013), 'Mobility, Migration and Rights in the European Union: Critical Reflections on Policy and Practice', Policy Studies 34, 2, 238-53.

Chong, D. (2008), 'Five Challenges to Legalizing Economic and Social Rights', Human Rights Review, 10, 2, 183-204.

Dahme, H. J. and Wohfahrt, N. (2013), Lehrbuch Kommunale Sozialverwaltung und Soziale Dienste, Weinheim und Bazel: Beltz Juventa.

Diakonie (2016), Auf einen Blick: Diakonie Deutschland. Selbstdarstellung, Stand April, 2011. Diakonie Deutschland - Evangelischer Bundesverband, Berlin.

Diakonie (2017), Jahresbericht 2016. Diakonie, Berlin-Brandenburg-schlesische Oberlausitz.

EESC (2017), 'How Civil Society Organisations Assist Refugees and Migrants in the EU'. Brussels: European Economic and Social committee.

Ehata, R. and Seeleib-Kaiser, M. (2017), 'Benefit tourism and EU citizens: Real-world experiences', in Hudson, J., Needham C. and Heins, E. (eds.), Social Policy Review 29: Analysis and Debate in Social Policy, Bristol: Policy Press, pp. 181-197.

Eurostat (2018a), Population on 1 January by age group, sex and citizenship [migr_pop1ctz]

Eurostat (2018b), Immigration by age, group, sex and citizenship [migr_imm1ctz]

Evers, A. (2005), 'Mixed Welfare Systems and Hybrid Organisations: Changes in the Governance and Provision of Social Services', International Journal of Public Administration, 28, 9-10, 737-48.

Evers, A. and Laville, J. L. (eds.) (2004), The Third Sector in Europe, Cheltenham/ Massachusetts: Edward Elgar.

Evers, A. and Olk, T. (1996), Wohlfahrtspluralismus. Vom Wohlfahrtsstaat zur Wohlfahrtsgesellschaft, Opladen: Leske und Budrich.

Frostschutzengel (2016), 'Aufsuchende Beratung für EU-Bürger_innen aus Mittelosteuropa in der niedrigschwelligen Wohnungslosenhilfe Berlin', Jahresbericht 2015 und Abschlussbericht, Berlin 08.2016.

Garkisch, M., Heidingsfelder, J. and Beckmann, M. (2017), 'Third Sector Organizations and Migration', Voluntas, 28, 1839-188o. 
Gothenburg (2013), 'Överenskommelse om Idéburet offentligt partnerskap. Insatser för migrerande EU medborgare i Göteborg', Gothenburg city, 10.2013.

Gothenburg City Mission (2016), Verksamhetsberättelse och årsredovisning 2015. Göteborgs kyrkliga stadsmission.

Goul Andersen, J. (2012), 'Convergence of Welfare Reforms in Social Services', Voluntas, 23, 515-519.

Henker, J. and Rink, A. (2017), 'Multiple Dimensions of Bureaucratic Discrimination: Evidence from German Welfare Office', American Journal of Political Science, 6, 4, 786-803.

Henriksen, L.S., Smith, S.R. and Zimmer, A. (2012), 'At the Eve of Convergence? Transformations of Social Service Provision in Denmark, Germany, and the United States', Voluntas, 23, 458-501.

Hien, J. (2017), 'From Private to Religious Patriarchy: Gendered Consequences of Faith-Based Welfare Provision in Germany', Politics and Religion, 10, 3, 515-42.

Johansson, H., Arvidsson, M. and Johansson, S. (2015), 'Welfare Mix as a Contested Terrain: Political Positions on Government-Non-profit Relations at National and Local Levels in a Social Democratic Welfare State', Voluntas, 26, 5, 1601-1619.

Kaufmann, F. X. (2014), European Foundations of the Welfare State, New York, Oxford: Berghan Books.

Lafleur, J. M. and Mescoli, E. (2018), 'Creating Undocumented EU Migrants through Welfare: A Conceptualization of Undeserving and Precarious Citizenship', Sociology, 52, 3, 480-96.

Leerkes, A. (2016), 'Back to the Poorhouse? Social Protection and Social Control of Unauthorised Immigrants in the Shadow of the Welfare State', Journal of European Social Policy 26, 2, 140-54.

Lewis, J. (1999), 'Reviewing the relationship between the voluntary sector and the state in Britain in the 1990s', Voluntas, 10, 3, 255-270.

Lundström, T. and Svedberg, L. (2003), 'The voluntary sector in a social democratic welfare state. The case of Sweden', Journal of Social Policy, 32, 2, 217-238.

Macmillan, R. (2010), 'The third sector delivering public services: an evidence review', Working Paper 20, Third Sector Research Centre, Birmingham.

Marshall, T. H. (1950), 'Citizenship and social class', in Marshall, T.H., ed., Citizenship and social class: And other essays, London: Pluto, 3-51.

Martinsen, D. S. and Werner, B. (2018), 'No Welfare Magnets - Free Movement and CrossBorder Welfare in Germany and Denmark Compared', Journal of European Public Policy $26,5,637-655$.

Merchel, J. (2010), 'Wohlfahrtsverbände, Dritter Sektor und Zivilgesellschaft, in Evers, A., Heinze, R. and Olk, T. H. (eds.), Handbuch Soziale Dienste, Wiesbaden: VS-Verlag, pp. $245-264$.

Morris, L. (2003), 'Managing Contradiction: Civic Stratification and Migrants' Rights', International Migration Review 37, 1, 74-100.

Nicolaou, A. (2018), Freedom of movement in the EU. ECAS report. Brussels.

O'Brien, N. (2012), 'Social rights and civil society: 'Giving Force' without 'Enforcement", Journal of Social Welfare and Family Law, 34, 4, 459-470.

PICUM. (2017), Cities of health: securing health care for undocumented migrants. PICUM, Brussels, April 2017.

Randall, A. (2015), 'Challenging the destitution policy: Civil society organisations supporting destitute migrants', Third Sector Research Centre, Working Paper 131.

Recchi, E. (2015), Mobile Europe. The Theory and Practice of Free Movement in the EU, Basingstoke: Palgrave Macmillan.

Römer, F. (2017), 'Generous to All or 'Insiders Only'? The Relationship between Welfare State Generosity and Immigrant Welfare Rights', Journal of European Social Policy, 27, 2, 173-96.

Ruhs, M. (2013), The price of rights, Princeton: Princeton University Press.

Sainsbury, D. (2012), Welfare States and Immigrant Rights: The Politics of Inclusion and Exclusion, Oxford, New York: OUP. 
Salvation Army (2016), Frälsningsarméns årsberättelse 2015. 06.2016, Stockholm.

Schmitt, C. and Teney, C. (2018), 'Access to General Social Protection for Immigrants in Advanced Democracies', Journal of European Social Policy, 29, 1, 44-55.

Shutes, I. (2016), 'Work-Related Conditionality and the Access to Social Benefits of National Citizens, EU and Non-EU Citizens', Journal of Social Policy, 45, 4, 691-707.

Sjödén, K. (2019), 'Att antalet människor som är hungriga ökar märks i varenda stad', Göteborgs-Posten, 2019-05-26.

SKL (2014), 'Några juridiska frågor gällande utsatta EU-medborgare. Sverige Landsting och Kommuner', Stockholm, 09.12.2014.

Stendahl, S. and Swedrup, O. (2016), 'A Legal Analysis of the Possibilities and Impediments for Citizens Seeking to Enforce their Social Rights', Deliverable 6.4, bEUcitizen, University Gothenburg.

Stockholm (2013), 'Riktlinjer för bidrag till ideella föreningar. Fastställd av Socialnämnden 2013-03-26', Dnr 3.1-103/2013, Stockholms City.

Stockholm City Mission (2016), Årsredovisning 2015: Stockholms Stadsmission. Stockholm 04.2016.

Tansey, O. (2007), 'Process Tracing and Elite Interviewing: A Case for Non-probability Sampling', PS: Political Science and Politics, 40, 4, 765-772.

Titmuss, R. (2010), 'Universalism versus Selection', in Pierson, C., Castles, F. G. and Naumann, I. K. (eds.), The Welfare State Reader, 3rd ed., Cambridge/Malden: Polity Press, 38-45.

Van der Waal, J., De Koster, W. and Van Oorschot, W. (2013), 'Three Worlds of Welfare Chauvinism? How Welfare Regimes Affect Support for Distributing Welfare to Immigrants in Europe', Journal of Comparative Policy Analysis: Research and Practice, $15,2,164-181$.

\section{Interviews}

Ger1 Public administrator, Neukölln district authority, Berlin, 09.12.2015.

Ger2 Social worker, Amaroforo, Berlin 16.11.2015

Ger3 Social worker, Mobile Contact Point for European migrant workers and Roma, Caritas, Berlin. 19.11.2015.

Ger4 Social worker, Frostschutzengel, Berlin, 24.11.2015.

Ger5 Follow-up interview, Frostschutzengel, Berlin, 29.06.2016

Ger6 Social worker, Migration counselling, Diakonie, Berlin, 09.12.2015.

Ger7 Social worker, Migration counselling, Verikom, Hamburg, 11.11.2015.

Ger8 Follow-up interview Verikom, Hamburg, 11.04.2017.

Ger9 Social worker, Housing Support, Diakonie, Hamburg, 12.11.2015

Ger1o Social worker, Office for Immigration from South-eastern Europe, Diakonie, Hamburg, 03.12.2015.

Ger11 Social worker, Migration counselling, Diakonie, Hamburg 02.12.2015.

Ger12 Social Worker, SOS - South-eastern Europe Service Centre, City Mission, Hamburg, 03.12.2015.

Swe1 Public administrator, Social Unit, Centrum district authority, Gothenburg, 16.02.2016.

Swe2 Social worker, Crossroads, City Mission, Gothenburg, 19.01.2016.

Swe3 Legal expert, Crossroads, City Mission, Gothenburg, 20.12.2016. 
Swe4 Follow up interview, Crossroads, City Mission, Gothenburg, 09.06.2017.

Swe5 Public administrator, Social Services, Stockholm Municipality, 26.08.2015.

Swe6 Social worker, Salvation Army, Stockholm, 18.09.2015.

Swe7 Social worker, Crossroads, City Mission, Stockholm, 26.08.2015.

Swe8 Public employment agency, Employment Services, Stockholm, 24.09.2015. 